\title{
Mycoplasma equigenitalium, a New Species from the Cervix Region of Mares
}

\author{
H. KIRCHHOFF \\ Institut für Mikrobiologie und Tierseuchen, Tierärztliche Hochschule Hannover, 3000 Hannover, Germany
}

\begin{abstract}
Eleven glucose-fermenting Mycoplasma strains isolated from the cervix region of mares exhibited serological properties which distinguished them from strains of the presently known Mycoplasma species. From the results obtained by growth inhibition, metabolic inhibition, indirect-immunofluorescence, and double-immunodiffusion tests, it can be concluded that these strains belong to a new species, for which the name Mycoplasma equigenitalium is proposed. The type strain of $M$. equigenitalium is T37 ( $=$ ATCC $29869=$ NCTC 10176).
\end{abstract}

Mycoplasmas and acholeplasmas have been reported to be present in the respiratory tract $(1,2,6,14,18,20,24)$, the genital organs $(15,20)$, the conjunctivae $(20)$, and the joints (6) of horses. Mycoplasmas and acholeplasmas have also been encountered in aborted horse fetuses $(13,16)$ and in stallion semen $(7,8)$.

To date, a total of 10 distinct Mycoplasmatales species have been found in horses: Acholeplasma laidlawii, $A$. oculi, $A$. granularum, $A$. axanthum, $A$. equifetale, $A$. hippikon (11a, 12), Mycoplasma pulmonis, $M$. felis, $M$. bovigenitalium, and $M$. equirhinis, a recently described species from the respiratory tract of horses (1).

The present report deals with the characterization and identification of 11 Mycoplasma strains previously isolated from the cervix region of mares (15).

\section{MATERIALS AND METHODS}

Mycoplasma strains. The 11 Mycoplasma strains used in this study (T33, T37, T84, T121, T122, T145, T199, T267, T270, T344, and T349) were obtained from cotton swabbings of the cervix region of mares (15). The isolates were each cloned three times by picking single colonies. The fluid culture was passed through a filter with an average pore diameter of $\mathbf{4 5 0}$ $\mathrm{nm}$, and dilutions of the filtrate were plated on a solid medium to produce well-separated colonies.

Culture media: The strains were cultivated in a medium of the following composition: heart infusion broth (Oxoid), $720 \mathrm{ml}$; unheated horse serum, $200 \mathrm{ml}$; $25 \%$ (wt/vol) fresh yeast extract, $10 \mathrm{ml}$; deoxyribonucleic acid (Sigma Chemical Co.), $0.02 \mathrm{~g} ; 1.25 \%$ (wt/vol) thallium acetate, $10 \mathrm{ml}$; and penicillin, $2 \times 10^{6} \mathrm{IU}$. Solid medium was prepared by adding $10 \mathrm{~g}$ of agar (Oxoid) to the fluid medium.

Morphological studies. Colonies were examined with a stereo microscope (Leitz). Cells from broth cultures were examined by dark-field and phase-contrast microscopy (Leitz).

Filtration characteristics. Filterability of the strains was determined by using Swinnex-25 adapters and membrane filters (Millipore Corp.) with a pore diameter of 450 or $200 \mathrm{~nm}$.

Reversion experiments. The strains were passaged seven consecutive times on substrate without penicillin and thallium acetate. Passages one to five, inclusive, were performed on solid media by sliding inverted agar blocks across the agar surfaces. In the sixth passage, the agar blocks were inoculated into noninhibiting fluid medium and, after incubation, the organisms were examined by dark-field microscopy. The seventh passage was made on solid medium.

Differentiation of acholeplasmas from mycoplasmas. Inhibition of growth by sodium polyanetholsulfonate (Liquoid, Roche Diagnostics) and by digitonin was tested by the disk method of Freundt et al. (11). The ability to grow at $22^{\circ} \mathrm{C}$ was determined as described by Leach (17). Determination of cholesterol requirement was made on solid medium by the method of Edward (9) as subsequently modified by Ernø and Stipkovits (10). Four different media were used: (A) basal medium (heart infusion agar) (Difco), $90.0 \mathrm{ml}$; $25 \%$ (wt/vol) yeast extract, $10.0 \mathrm{ml} ; 0.2 \%$ (wt/vol) deoxyribonucleic acid (Sigma Chemical Co.), $1.2 \mathrm{ml}$; $10 \%(\mathrm{wt} / \mathrm{vol})$ thallium acetate, $1.0 \mathrm{ml}$; and penicillin, $2 \times 10^{6} \mathrm{IU} / \mathrm{ml}$; (B) as (A) but with $10 \mu \mathrm{g}$ of palmitic acid per $\mathrm{ml}$ and $0.5 \%$ bovine serum albumin; (C) as (B) but with $5 \mu \mathrm{g}$ of cholesterol per $\mathrm{ml}$; (D) as (A) but with 1.0\% PPLO serum fraction (Difco). The cultures were centrifuged and washed three times in phosphatebuffered saline (pH 7.4). The sediment was resuspended in phosphate-buffered saline, and plates with media A to D were inoculated with $0.05 \mathrm{ml}$ of 10 -fold dilutions (from $10^{0}$ to $10^{-6}$ ) of this suspension. One set of plates was incubated at $37^{\circ} \mathrm{C}$ under normal atmospheric conditions, and another set was incubated at $37^{\circ} \mathrm{C}$ in an atmosphere of $5 \% \mathrm{CO}_{2}$.

Biochemical tests. Breakdown of the following carbohydrates (1\%) was determined by the method of Aluotto et al. (3): glucose, lactose, maltose, saccharose, galactose, fructose, arabinose, sorbitol, rhamnose, xylose, mannose, trehalose, dulcitol, inositol, and salicin. The mycoplasmas were also examined for their ability to hydrolyze arginine $(1 \%)$ and urea $(1 \%)$, to reduce 2,3,5-triphenyltetrazolium chloride $(0.02 \%)$, potassium tellurite $(0.00125 \%, 0.0025 \%$, and $0.005 \%)$, and methylene blue $(0.0033 \%)$; to hydrolyze gelatin; to digest 
casein and coagulated serum; and to produce phosphatase (3). The production of "film and spots" (5) was determined on an agar medium supplemented with $10 \%$ egg yolk emulsion (Oxoid) and $20 \%$ horse serum and on a medium containing $10 \%$ egg yolk emulsion and $20 \%$ swine serum. Hydrolysis of esculin and arbutin was tested by the methods of Ernø and Stipkovits (10).

Hemalysis and hemadsorption. The overlay technique (3) was used to test for hemolysis. Hemadsorption was determined as described by Sobeslavsky et al. (22). Both tests were performed with equine, bovine, ovine, canine, rabbit, guinea pig, and chicken erythrocytes.

Preparation of antisera. For the preparation of

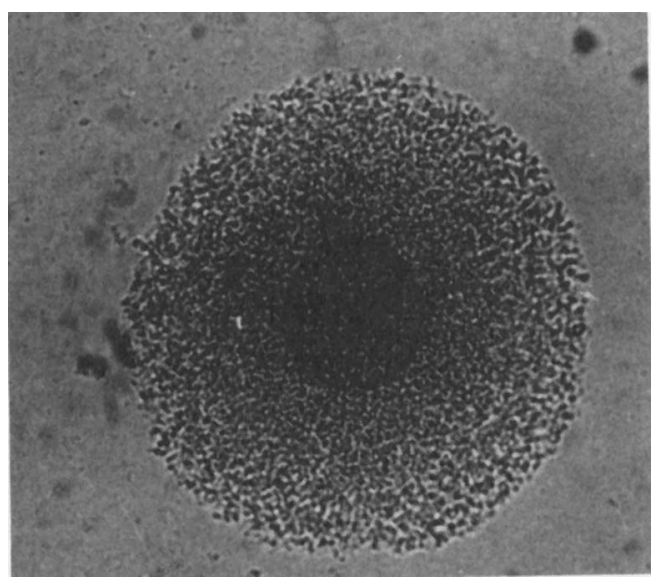

FIG. 1. Unstained colony of strain T37 showing typical "fried egg" morphology. $\times 160$.

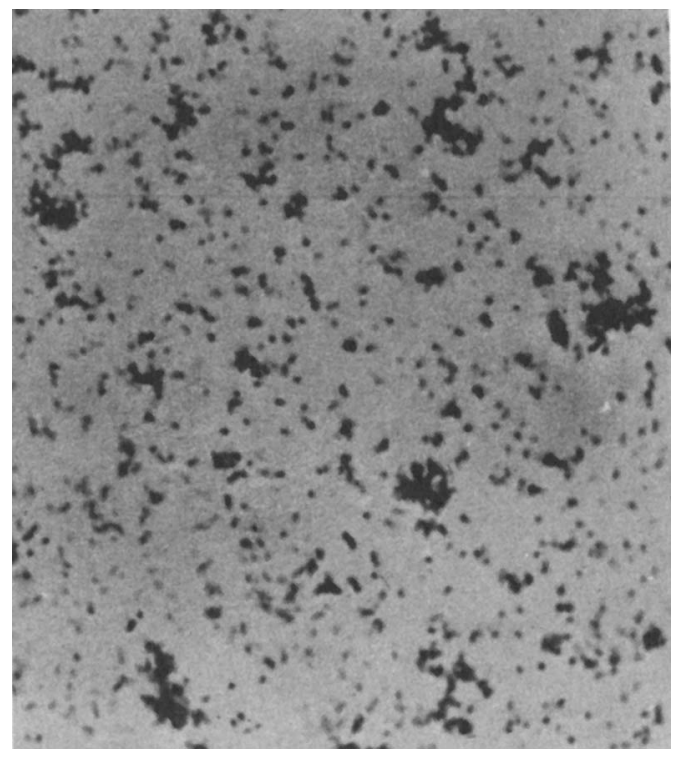

Fig. 2. Cells from a broth culture of strain T37 (Giemsa stain). $\times 3,600$.

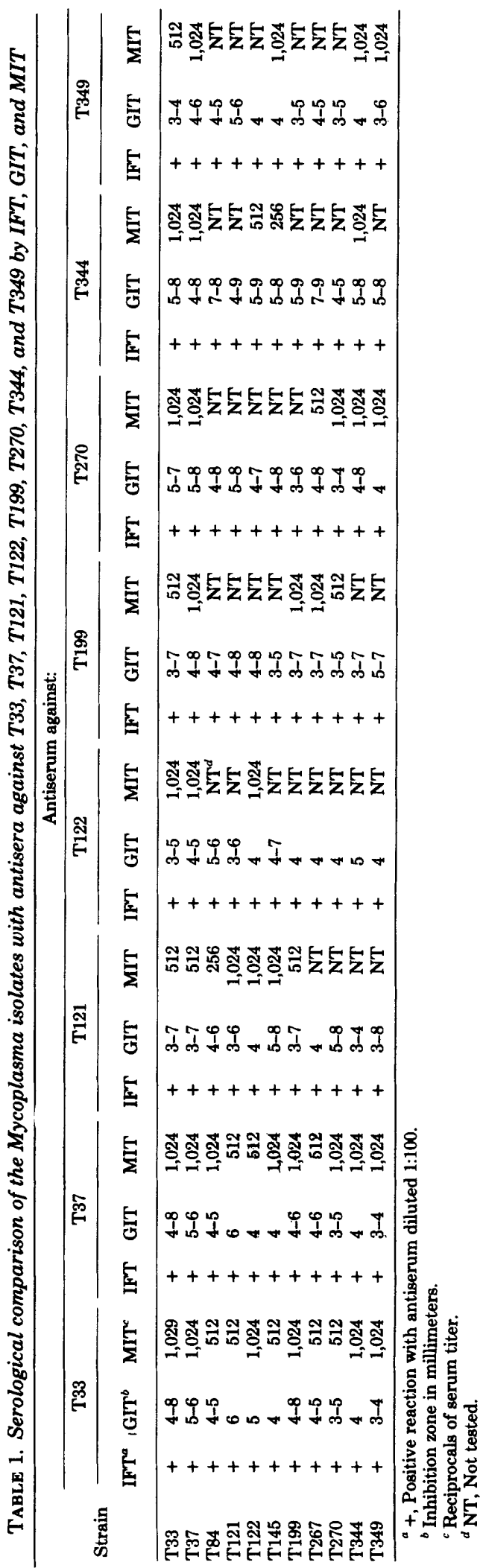


antisera, organisms were cultivated in a medium consisting of phosphate-buffered saline, $765 \mathrm{ml}$; heated swine serum, $200 \mathrm{ml} ; 25 \%$ (wt/vol) fresh yeast extract, $10 \mathrm{ml}$; glucose, $2.5 \mathrm{~g}$; lactalbumin (hydrolyzed), $5 \mathrm{~g}$; $1.25 \%(\mathrm{wt} / \mathrm{vol})$ thallium acetate, $10 \mathrm{ml}$; and penicillin, $2 \times 10^{6} \mathrm{IU} / \mathrm{ml}$. The mycoplasmas were passaged six to eight times in this medium to eliminate traces of horse serum. They were then washed two times in buffered saline, resuspended in 0.01 of the initial volume, emulsified in the same volume of complete Freund adjuvant (Difco), and administered to rabbits by the method of Morton and Roberts (19).

Serological tests. The mycoplasmas were compared by the disk growth inhibition test (GIT) according to the method of Clyde (4), the metabolic inhibition test (MIT) as described by Taylor-Robinson et al. (23), the indirect-immunofluorescence test (IFT) for colonies (5), and the double-immunodiffusion technique (21). For the GIT, mycoplasma cultures were diluted 1:100, 1:500, and 1:1,000 and were then tested against undiluted antiserum. The plates were incubated at $37^{\circ} \mathrm{C}$ and were read shortly after development of colonies. The MIT was performed with microtiter plates. Besides undiluted antigen, dilutions 1:10, 1:100,
$1: 1,000$, and $1: 10,000$ were tested against the serum dilutions in a medium containing glucose or arginine $(1 \%)$, horse serum $(20 \%)$, and yeast extract $(1 \%)$ in Difco PPLO broth. The microtiter plates were incubated at $37^{\circ} \mathrm{C}$. In the GIT and MIT, tests with the optimal antigen concentration were selected for evaluation. For the IFT, only young colonies ( 1 or 2 days old) were used because autofluorescence was sometimes encountered with older colonies. Antisera were used in dilutions of 1:10 and 1:100. For gel diffusion, organisms were washed twice in saline $(0.25 \mathrm{M})$, suspended in $1 \%$ sodium deoxycholate in phosphatebuffered saline ( $\mathrm{pH} \mathrm{8.5)}$, representing a 100 -fold concentration, and kept overnight at room temperature. The extract was centrifuged $(20,000 \times g$ for $30 \mathrm{~min})$, and the supernatant, after dialysis against distilled water, was used as antigen.

\section{RESULTS}

Morphological and cultural characteristics. Colonies of all of the isolates studied exhibited the "fried egg" morphology typical of mycoplasmas: a marked central spot on solid

TABLE 2. Sources of antisera used against glucose-utilizing Mycoplasma strains ${ }^{a}$

\begin{tabular}{|c|c|c|c|}
\hline \multirow{2}{*}{ Strain } & \multicolumn{3}{|c|}{ Source of antisera used in: } \\
\hline & MIT & GIT & IFT \\
\hline Mycoplasma alvi Ilsley & IRC & IRC & IRC \\
\hline M. anatis $1340 \ldots \ldots$ & NIH, IMT & NIH & NIH, IMT \\
\hline M. bovirhinis PG43 & NIH, IMT & NIH, IMT & NIH, IMT \\
\hline M. bovoculi M165/69 & IRC & IRC & IRC \\
\hline M. canis PG14 .... & NIH, IRC, IMT & NIH, IMT & IRC, IMT \\
\hline M. capricolum Cal. kid & IRC & IRC & IRC \\
\hline M. caviae G122 ...... & NIH, IMT & NIH, IMT & NIH \\
\hline$M$. conjunctivae HRC581 & NIH, IMT & NIH, IMT & NIH, IMT \\
\hline M. cynos H831 . . . . . . & IMT & IMT & IMT \\
\hline M. dispar $462 / 2$ & IRC, IMT & IRC, IMT & IRC, IMT \\
\hline M. edwardii PG24 & IRC, IMT & IRC, IMT & IRC, IMT \\
\hline M. feliminutum Ben & IRC & IRC & IRC \\
\hline M. felis $\mathrm{CO} \ldots \ldots$ & NIH, IMT & NIH, IRC, IMT & NIH, IMT \\
\hline$M$. fermentans $\mathrm{PG} 18$ & NIH, IMT & NIH, IMT & NIH, IMT \\
\hline M. flocculare Ms42. & SVS & SVS & SVS \\
\hline M. gallisepticum PG31 & NIH, IMT & NIH, IMT & NIH, IMT \\
\hline M. hyopneumoniae Ja & IMT & IMT & IMT \\
\hline M. hyorhinis BTS7 & NIH, CVM & NIH, CVM & NIH, CVM \\
\hline M. hyorhinis GDL . & NIH, CVM & NIH, CVM & NIH, CVM \\
\hline M. moatsi MK405 & IRC & IRC & IRC \\
\hline M. molare H542 & IMT & IMT & IMT \\
\hline M. mycoides subsp. mycoides PG1 & IRC & IRC & IRC \\
\hline M. mycoides subsp. capri PG3 ... & IRC & IRC & IRC \\
\hline M. neurolyticum ТурА ....... & NIH, IMT & NIH, IMT & NIH, IMT \\
\hline M. ovipneumoniae Y98 & IMT & IMT & IMT \\
\hline$M$. pneumoniae $\mathrm{FH}$ & NIH, IMT & NIH, IMT & NIH, IMT \\
\hline M. pulmonis PG34. & NIH, IMT & NIH, IMT & NIH, IMT \\
\hline M. putrefaciens $\mathrm{KS} 1$ & IMT & IMT & IMT \\
\hline M. synoviae WVV1853 & IRC & IRC & IRC \\
\hline
\end{tabular}

${ }^{a}$ Abbreviations: CVM, (R. F. Ross) College of Veterinary Medicine, Iowa State University, Ames, Iowa; IRC, (E. A. Freundt) FAO/WHO International Reference Centre for Animal Mycoplasma, Aarhus, Denmark; MIT, (J. Heitmann) Mikrobiologisches Institut der Tierärztlichen Hochschule, Hannover, Germany; NIH, (M. F. Barile and J. Tully) National Institutes of Health, Bethesda, Maryland; SVS, (N. F. Friis) Statens Veterinaere Serumlaboratorium, Copenhagen, Denmark. 
TABLE 3. Sources of antisera used against nonfermentative Mycoplasma strains ${ }^{a}$

\begin{tabular}{|c|c|c|}
\hline \multirow{2}{*}{ Strain } & \multicolumn{2}{|c|}{ Source of antiserum used in: } \\
\hline & MIT & IFT \\
\hline Mycoplasma agalactiae PG2 . . . . & IRC & IRC \\
\hline M. alkalescens PG51 & & NIH \\
\hline M. arginini G230. & $\mathrm{NIH}$ & NIH, IMT \\
\hline$M$. arthritidis $\mathrm{PG} 6$ & IMT & NIH, IM'T \\
\hline M. bovigenitalium PG43 $\ldots \ldots \ldots$ & NIH, IMT & NIH, IMT \\
\hline M. bovis PG45 $\ldots \ldots \ldots \ldots \ldots \ldots$ & IRC, IMT & IRC, IMT \\
\hline M. buccale CH $20247 \ldots \ldots \ldots \ldots \ldots$ & & NIH \\
\hline M. canadensis $275 \mathrm{C}$ & & IMT \\
\hline M. equirhinis M $432 / 72$ & IMT & IMT \\
\hline M. faucium DC333 ... & NIH & NIH \\
\hline M. gallinarum PE16 & IMT & IMT, NIH \\
\hline M. gatae CS . . . . & IMT & IMT \\
\hline M. hominis PG21 & NIH & NIH \\
\hline M. hyosynoviae S16 & CVM & CVM \\
\hline$M$. iners PG30 . . . & & NIH \\
\hline M. lipophilum MaBy & IRC & IRC \\
\hline M. maculosum PG15 & & IRC, IMT \\
\hline M. meleagridis 17529 & & IRC \\
\hline M. orale $\mathrm{CH} 19299$ & NIH & NIH \\
\hline M. opalescens MH5408 & IMT & IMT \\
\hline M. primatum HRC292. & NIH & NIH \\
\hline M. salivarium PG20 & & NIH \\
\hline M. spumans PG13. & & IRC, IMT \\
\hline$M$. verecundum 107 & IMT & IMT \\
\hline
\end{tabular}

${ }^{a}$ See footnote $a$ of Table 2 for abbreviations.

medium (Fig. 1). Growth in fluid media reached a maximum between 3 and 5 days of incubation at $37^{\circ} \mathrm{C}$. All isolates grew both aerobically and under $5 \% \mathrm{CO}_{2}$. Phase-contrast and dark-field microscopy of the fluid cultures showed pleomorphic organisms, with coccoid elements dominating. Larger conglomerates were also present (Fig. 2). The colonial and cellular morphologies of the isolates were indistinguishable from those of other mycoplasmas.

Filterability and reversion. All of the strains passed filters with average pore diameters of 450 and $200 \mathrm{~nm}$ with a decrease of about $10^{2}$ colony-forming units per ml. No bacteriallike colonies developed on the noninhibiting substrate during seven passages.

Differentiation of acholeplasmas from mycoplasmas. None of the isolates grew at $22^{\circ} \mathrm{C}$. All were inhibited by 5 and $10 \%$ sodium polyanethol sulfonate or $1.5 \%$ digitonin. Inhibition zones of 7 to $12 \mathrm{~mm}$ were observed. None of the 11 strains grew on the serum free-substrate (A) or on the substrate with palmitic acid and bovine serum albumin added (B). On the substrate containing cholesterol (C), growth occurred on plates inoculated with an undiluted suspension or with a $10^{-1}$ dilution, and weak growth occurred with a $10^{-2}$ or $10^{-3}$ dilution. On the substrate containing the PPLO serum fraction (D), growth occurred on plates inoculated with undiluted suspension or with a $10^{-1}, 10^{-2}$, or $10^{-3}$ dilution, and weak growth occurred with a $10^{-4}$ dilution. On culture medium, growth was observed on plates inoculated with dilutions up to and including $10^{-6}$.

Biochemical characteristics. All of the isolates studied showed the same biochemical features. They were found to ferment various carbohydrates aerobically as well as anaerobically. All of the investigated carbohydrates were utilized; however, the acid production varied depending on the carbohydrates used and was not always reproducible. All strains were found to be unable to hydrolyze arginine and urea and to reduce 2,3,5-triphenyltetrazolium chloride and methylene blue. Potassium tellurite was reduced by all strains, and the reduction was influenced by various factors, especially the size of the colonies, the duration of incubation, and the concentration of the potassium tellurite. Potassium tellurite reactions were negative on plates with dense growth; large, single colonies usually developed a black coloration, indicative of a positive reaction. The intensity of the coloration increased with the length of time of incubation. Generally, the most intense coloration was attained after 7 days of incubation. All of the isolates were inhibited by a concentration of $0.005 \%$ potassium tellurite and, therefore, lower concentrations $(0.0025 \%$ and $0.00125 \%)$ were 
TABLE 4. Mycoplasma strains investigated with antisera against strains T33 and T37

\begin{tabular}{|c|c|c|}
\hline Strain & Source & $\begin{array}{l}\text { MIT, GIT, } \\
\text { IFT }\end{array}$ \\
\hline M. agalactiae PG2 & $\operatorname{IRC}^{a}$ & $-{ }^{b}$ \\
\hline M. alvi Ilsley & IRC & - \\
\hline$M$. anatis $1340 \ldots \ldots$ & NIH & - \\
\hline M. bovigenitalium PG11 & NIH & - \\
\hline M. bovirhinis PG43 ...... & NIH & - \\
\hline M. bovis PG45 ... & IRC & - \\
\hline M. bovoculi M165/69 & IRC & - \\
\hline M. canis PG14 . . . . & NIH & - \\
\hline M. capricolum Cal. kid & IRC & - \\
\hline M. caviae G122 . . . . & IRC & - \\
\hline M. conjunctivae HRC581 & IRC & - \\
\hline M. cynos H831 . . . . . . & IRC & - \\
\hline M. dispar $462 / 2$ & IRC & - \\
\hline M. edwardii PG24 & IRC & - \\
\hline M. feliminutum Ben & IRC & - \\
\hline M. felis $\mathrm{CO} \ldots \ldots$ & IRC & - \\
\hline M. fermentans PG18 & NIH & - \\
\hline M. gallisepticum PG31 . . . & NIH & 一 \\
\hline M. hyopneumoniae Ja. & SVS & - \\
\hline M. hyorhinis BTS7 ... & NIH & - \\
\hline M. hyorhinis GDL . . & NIH & - \\
\hline M. moatsi MK405 & IRC & - \\
\hline M. molare $\mathrm{H} 542$. & IRC & - \\
\hline M. neurolyticum ТypA ... & NIH & - \\
\hline M. ovipneumoniae Y98 . . & IRC & - \\
\hline M. pneumoniae FH & NIH & - \\
\hline M. pulmonis PG34. & NIH & - \\
\hline M. putrefaciens KS1 & IRC & 一 \\
\hline M. verecundum 107 . & NIH & - \\
\hline
\end{tabular}

${ }^{a}$ See footnote $a$ of Table 2 for abbreviations.

$b$, No reaction.

used. The intensity of the coloration was not influenced by a diminution of the concentration of the potassium tellurite. Digestion of coagulated serum, hydrolysis of gelatin, esculin, and arbutin, and digestion of casein were not observed. All of the strains produced phosphatase. Production of "film and spots" occurred on a medium with $10 \%$ egg yolk emulsion and $20 \%$ horse serum after incubation for 7 days but not on a medium with $10 \%$ egg yolk emulsion and $20 \%$ swine serum or on culture medium.

Hemolysis occurred with equine, bovine, ovine, canine, rabbit, guinea pig, and chicken erythrocytes. Hemadsorption did not occur with these erythrocytes.

Serology. In the first step, the strains were investigated with antisera against strains T33, T37, T121, T122, T199, T270, T344, and T349 by IFT, GIT, and MIT (Table 1). The investigations indicated that the 11 isolates have the same serological features and belong to the same serological group.
For a comparison of the isolates with the type strains of the established Mycoplasma species, strains T33 and T37 were chosen as representatives. They were tested against antisera prepared from the glucose-utilizing Mycoplasma strains listed in Table 2 by MIT, GIT, and IFT and against the antisera prepared from the nonfermentative Mycoplasma strains listed in Table 3 by IFT and, in some cases (host change, same habitat), also by MIT. The reciprocal test was done with antisera against T33 and T37 on the Mycoplasma strains listed in Table 4. MIT, GIT, and FIT were carried out.

In all of these investigations, no positive reaction was observed.

The relationship of strains T33 and T37 to other glucose-utilizing mycoplasmas, as determined by the double-immunodiffusion technique, is shown in Table 5. The reactions with the homologous antisera gave five to six, and with the antisera against other species none or one to three, precipitation lines.

\section{DISCUSSION}

The colonial morphology, pleomorphic cell form in fluid culture, passage of 450- and 200nm-pore-size filters, and stability (on noninhibiting substrate) of the isolates indicate that they belong to the order Mycoplasmatales.

The inability of the isolates to grow at $22^{\circ} \mathrm{C}$, their susceptibility to sodium polyanethol sulfonate and digitonin, and their cholesterol requirement confirm that the isolates belong to the family Mycoplasmataceae.

All of the isolates showed the same biochemical and serological features, indicating that they belong to the same taxon. Representative strains (T33 and T37) of the group differed from the established Mycoplasma species when tested by the IFT, GIT, MIT, and double-immunodiffusion test.

From these results, it can be concluded that the 11 isolates (T33, T37, T84, T121, T122, T145, T199, T267, T270, T344, and T349) represent a new species of the genus Mycoplasma for which the name Mycoplasma equigenitalium (e.qui.ge.ni.tá li.um. L.noun equus, equi the horse; M.L. pl.n. genitalia the genitals; M.L. pl. gen.n. equigenitalium of equine genitalia) is proposed. The specific epithet indicates the host and the isolation site. The type strain of $M$. equigenitalium is T37. This strain has been deposited in the American Type Culture Collection, Rockville, Md., under the number ATCC 29869 and in the National Collection of Type Cultures, London, England, under the number NCTC 10176. 
TABLE 5. Relationships of strains T33 and T37 with other mycoplasmas as determined by the doubleimmunodiffusion technique

\begin{tabular}{|c|c|c|c|}
\hline \multirow{2}{*}{ Antiserum against: } & \multirow{2}{*}{ Source of antiserum ${ }^{a}$} & \multicolumn{2}{|c|}{ No. of precipitation lines } \\
\hline & & Strain T33 & Strain T37 \\
\hline Mycoplasma agalactiae & $\operatorname{IRC}^{a}$ & - & - \\
\hline M. alvi Ilsley . . . . . . . . . . . . & IRC & 2 & 2 \\
\hline M. anatis ........ & NIH & 1 & $1(2)$ \\
\hline \multirow[t]{2}{*}{ M. bovigenitalium } & NIH & (1) & 1 \\
\hline & IMT & (1) & (1) \\
\hline M. bovirhinis & IMT & (2) & 1 \\
\hline \multirow{2}{*}{ M. bovis PG45 . . . . . . . . . . . } & IRC & - & - \\
\hline & IMT & 1 & 1 \\
\hline 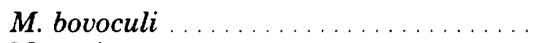 & IRC & 2 & 1 \\
\hline \multirow{2}{*}{ M. canis . . . . . . . . . . } & NIH & (1) & - \\
\hline & IMT & (2) & 3 \\
\hline M. capricolum & IRC & (1) & - \\
\hline \multirow[t]{2}{*}{ M. caviae ... } & NIH & 1 & 1 \\
\hline & IMT & (1) & 2 \\
\hline M. conjunctivae & IMT & (1) & 3 \\
\hline$\ldots \ldots \ldots \ldots \ldots \ldots$ & IMT & (1) & 2 \\
\hline$\ldots \ldots \ldots \ldots \ldots \ldots$ & IMT & 2 & 2 \\
\hline$\ldots \ldots \ldots \ldots \ldots$ & IMT & (1) & - \\
\hline$M$. feliminutum $\ldots \ldots \ldots \ldots \ldots$ & IRC & - & - \\
\hline \multirow{2}{*}{$M$. felis . . . . . . . . . . . . . . } & NIH & (2) & $2(1)$ \\
\hline & IMT & (1) & - \\
\hline \multirow{2}{*}{ M. fermentans } & NIH & (1) & (1) \\
\hline & IMT & (2) & 2 \\
\hline$\ldots \ldots \ldots \ldots \ldots$ & SVS & 3 & 3 \\
\hline M. gallisepticum & NIH & - & - \\
\hline M. hyopneumoniae $\ldots \ldots \ldots \ldots \ldots \ldots$ & IMT & - & - \\
\hline \multirow[t]{2}{*}{$M$. hyorhinis $\ldots \ldots \ldots \ldots \ldots \ldots \ldots$} & NIH & 1 & $(2)$ \\
\hline & IMT & - & - \\
\hline$\ldots \ldots \ldots \ldots \ldots \ldots$ & IRC & - & - \\
\hline$\ldots \ldots \ldots \ldots \ldots$ & IMT & 1 & (1) \\
\hline M. mycoides subsp. mycoides . . . . . . & IRC & 1 & - \\
\hline \multirow[t]{2}{*}{$M$. neurolyticum $\ldots \ldots \ldots \ldots \ldots \ldots$} & NIH & - & - \\
\hline & IMT & 1 & 2 \\
\hline M. ovipneumoniae $\ldots \ldots \ldots \ldots \ldots$ & IMT & 1 & 2 \\
\hline \multirow[t]{2}{*}{ M. pneumoniae . . . . . . . . . . . } & NIH & 2 & 2 \\
\hline & IMT & - & - \\
\hline \multirow[t]{2}{*}{ M. pulmonis } & NIH & - & - \\
\hline & IMT & - & $1(1)$ \\
\hline M. putrefaciens & IMT & (1) & 1 \\
\hline M. synoviae & IRC & 1 & 1 \\
\hline M. verrecundum & IMT & (1) & 2 \\
\hline Strain T33 $\ldots \ldots \ldots \ldots \ldots \ldots \ldots$ & IMT & 5 & 6 \\
\hline$\ldots \ldots \ldots \ldots \ldots \ldots$ & IMT & 5 & 5 \\
\hline$\ldots \ldots \ldots \ldots \ldots \ldots$ & IMT & 6 & 5 \\
\hline Strain T349 $\ldots \ldots \ldots \ldots \ldots \ldots$ & IMT & 5 & 5 \\
\hline
\end{tabular}

${ }^{a}$ See footnote $a$ of Table 2 for abbreviations.

${ }^{b}$ Dashes indicate no reaction. Parentheses indicate weak precipitation lines.

\section{ACKNOWLEDGMENTS}

I am greatly indebted to M. F. Barile, E. A. Freundt, R. F. Ross, and J. Tully for providing cultures of Mycoplasma strains, antisera for comparison, and much valuable advice. Work was facilitated by the exellent technical assistance of Hilma Dubenkropp and Rosemarie Schmidt. Investigations were supported by a grant from the
Deutsche Forschungsgemeinschaft, Bonn, Bad Godesberg, Germany.

\section{REPRINT REQUESTS}

Address reprint requests to: Dr. H. Kirchhoff, Institut für Mikrobiologie und Tierseuchen der Tierärztlichen Hochschule Hannover, Bischofsholer Damm 15, 3000 Hannover, Germany. 


\section{LTERATURE CITED}

1. Allam, N. M., and R. M. Lemcke. 1975. Mycoplasmas isolated from the respiratory tract of horses. J. Hyg. $74: 385-407$.

2. Allam, N. M., D. G. Powell, B. E. Andrews, and R. M. Lemcke. 1973. The isolation of Mycoplasma species from horses. Vet. Rec. 93:402.

3. Aluotto, B. B., R. G. Wittler, C. O. Williams, and J. E. Faber. 1970. Standardized bacteriologic techniques for the characterization of Mycoplasma species. Int. J. Syst. Bacteriol. 20:35-58.

4. Clyde, W. A. 1964. Mycoplasma species identification based upon growth inhibition by specific antisera. J. Immunol. 92:958-965.

5. Del Giudice, R. A., F. Robillard, and T. R. Carski. 1967. Immunofluorescence identification of $\mathrm{Myco}$ plasma on agar by use of incident illumination. J. Bacteriol. 93: 1205-1209.

6. Dellinger, J. D., and D. E. Jasper. 1972. Polyacrylamide-gel electrophoresis of cell proteins of mycoplasma isolated from cattle and horses. Am. J. Vet. Res. 33:769-775.

7. Donker-Voet, J., and J. De Bok. 1968. Ene oderzoek naar het voorkomen van mycoplasmas (PPLO) in het sperma van beren en hengsten. Tijdschr. Diergeneeskd. 93:912-916.

8. Donker-Voet, J., and S. C. Goelst. 1972. Mycoplasma's in hengst sperma en hun gevoeligheid in vitro voor enkele antibiotika en chemotherapeutika. Tijdschr. Diergeneeskd. 97:412-417.

9. Edward, D. G. 1971. Determination of sterol requirement for Mycoplasmatales. J. Gen. Microbiol. 69:205-210.

10. Ernø, H., and L. Stipkovits. 1973. Bovine mycoplasmas cultural and biochemical studies. Acta Vet. Scand. 14:436-449.

11. Freundt, E. A., B. E. Andrews, H. Ernø, M. Kunze, and F. T. Black. 1973. The sensitivity of Mycoplas matales to sodium polyanethol-sulfonate and digitonin. Zentralbl. Bakteriol. Parasitenkd. Infektionskr. Hyg. Abt. 1 Orig. Reihe A 225:104-112.

11a. Kirchhoff, H. 1974. Neǔe Species der Fam. Acholeplasmataceae ŭnd der Fam. Mycoplasmataceae bei Pferden. Zentralbl. Veterinaermed. Reihe B 21:207-210.
12. Kirchhoff, H. 1978. Acholeplasma equifetale and Acholeplasma hippikon, two new species from aborted horse fetuses. Int. J. Syst. Bacteriol. 28:76-81.

13. Kirchhoff, H., W. Bisping, and W. Floer. 1973. Nachweis von Acholeplasmen und Mykoplasmen in abortierten Pferdefeten. Berl. Muench. Tieraerztl. Wochenschr. 86:401-403.

14. Kirchhoff, H., E. Deegen, E. Zeller, and W. Floer. 1972. Nachweis von Mycoplasmen in Luftsack und Pharynx von Pferden mit akuten Erkrankungen der Respirationsorgane. Dtsch. Tieraerztl. Wochenschr. 79:465-468.

15. Krabisch, P., H. Kirchhoff, and Frhr. J. von Lepel. 1973. Nachweis von Mykoplasmen auf Genitalschleimhäuten von Stuten. Dtsch. Tieraerztl. Wochenschr. 80:493-495.

16. Langford, E. V. 1974. Isolation of Mycoplasma bovigenitalium from an aborted equine fetus. Vet. Rec. 94:528.

17. Leach, R. H. 1973. Further studies on classification of bovine strains of mycoplasmatales, with proposals for new species, Acholeplasma modicum and Mycoplasma alkalescens. J. Gen. Microbiol. 75:135.

18. Moorthy, A. R. S., and P. B. Spradbrow. 1976. Isolation of mycoplasmas from the respiratory tract of horses in Australia. Vet. Rec. 98:235-237.

19. Morton, H. E., and R. J. Roberts. 1966. Production of antimycoplasma (PPLO) antibodies in rabbits. Proc. Soc. Exp. Biol. Med. 125:538-542.

20. Ogata, M., J. Watabe, and K. Koshimizu. 1974. Classification of acholeplasmas isolated from horses. Jpn. J. Vet. Sci. 36:43-51.

21. Ouchterlony, C. 1949. Antigen antibody reactions in gels. Acta Pathol. Microbiol. Scand. 26:507.

22. Sobeslavsky, O., B. Prescott, and R. M. Chanock. 1968. Adsorption of Mycoplasma pneumoniae to neuramic acid resceptors of various cells and possible role in virulence. J. Bacteriol. 96:695-705.

23. Taylor-Robinson, D., R. H. Purcell, D. C. Wong, and R. M. Chanock. 1966. A colour test for the measurement of antibody to certain Mycoplasma species based upon the inhibition of acid production. J. Hyg. 64:91-104.

24. Windsor, G. D., 1973. The isolation of mycoplasma from horses. Vet. Rec. 93:593-594. 